UDC 338.48

DOI 10.26906/eip.2019.1(72).1432

JEL classification: D47

\title{
PROBLEMS OF THE INTERNATIONAL TOURISM MARKET IMPROVEMENT IN GEORGIA
}

\author{
Anzor Devadze *, Ph.D, Professor, Head of Tourism Department \\ Irakli Kordzaia**, D.Sc., Assoc. Professor \\ Batumi Shota Rustaveli State University. \\ Kseniia Chichulina ***, Ph.D., Assoc. Professor \\ Poltava National Technical Yuri Kondratyuk University.
}

* ORCID 0000-0001-6344-7385

**ORCID 0000-0003-0614-1069

***ORCID 0000-0001-7448-0180

(C) Devadze A., 2019.

(C) Kordzaia I., 2019.

(C) Chichulina K., 2019.

Стаття отримана редакиією 28.02.2019 р.

The article was received by editorial board on $28.02 .2019 p$.

Introduction. In world practice, international tourism is becoming a significant component of the global socio-economic program. This program involves the transfer of a large part of the population from the production sector to the service sector and to a large extent creates objective prerequisites for the search and application of the most perfect ways to improve the tourism industry. This will enhance the competitiveness of the country's tourism market.

Georgia has almost unlimited resources for the development of international tourism due to its geopolitical location and existing natural, historical and cultural resources. Based on the above, the relevance of the study is justified by the objective need for sustainable development and effective use of the tourism market of Georgia. This will contribute to the further development of the country's international tourism in the context of globalization. At the same time, the further development of international tourism will reduce the level of unemployment, migration and other negative phenomena, will contribute to the redistribution of excess labor resources from production to alternative service sectors.

Review of the recent research and publications sources. The problem of improvement and further development of international tourism is recognized as the most important in the theory and practice of the tourism industry in the world. This problem is the subject of study of many scientists.

Foreign experience of tourism development in the conditions of global competition, management and marketing in the process of creation and development of the national tourism industry, the concept of state tourism branding are presented in the works by Stuart Crainer, Des Dearlove [1, 2], Lee Cockerell [ 3] and others.

General approaches to the analysis of the markets of tourism markets are presented in [4-7]. The study [4] adopts an advanced panel club convergence approach to analyzing global tourism market segmentation. Authors empirically examine the convergence process of Turkish global tourism source markets over the period of 2001-2015, covering 81 markets. We further employ a recently developed procedure to test for structural breaks in our data. Three groups of breakpointhomogenous countries are identified. Then we examine within-group club formation and reveal a number of convergence clubs (or segments). The results show the importance of Asian source markets in the post-break periods. This study illustrates the application of structural break and club convergence analysis for segmenting global tourism markets, and generates important implications 
for tourism organizations to develop global marketing strategies. The expansion of tourism can cause environmental deterioration, such that tourism has a very high environmental cost in relation to the benefits it brings to those societies hosting it. In such a context, research [5] aims to investigate the relationships that may exist between the expansion of touristic activity and environmental sustainability, with its main objective being to substantiate that the relationship between tourism and environmental sustainability is not unidirectional, as well as to establish that sustainability influences the expansion of touristic activity. For this, structural equation models have been used to measure the possible relationships between tourism growth and environmental sustainability, by using a sample of 139 countries with data from the last ten years. The work shows, in line with the position of international organizations, that the expansion of tourism translates into an environmental deterioration of the destination (risk dimension) and, furthermore, it substantiates that there are specific variables connected to environmental sustainability (regulatory dimension) that contribute to greater tourism growth, so that the relationship between tourism and environmental sustainability is bidirectional. Based on these results, stakeholders in a tourist destination should commit to greater compliance with environmental regulations as it translates into growth of touristic activity, as well as to limiting the risk factors that said activity represents for the environment and its potential for future growth. The paper [6] estimates a total factor productivity index that allows for a rich decomposition of productivity in the tourism industry. We account for two important characteristics: First, the heterogeneity between multiple tourism destinations, and second, the potential endogeneity in inputs. Importantly we develop our index at the macro level, focusing on cross-country comparisons. Using the Bayesian approach, authors test the performance of the model across various priors. Authors rank tourism destinations based on their tourism productivity and discuss the main sources of productivity growth. Authors also provide long-run productivity measures and discuss the importance of distinguishing between short-run and long-run productivity measures for future performance improvement strategies. Understanding geospatial demand for destinations can improve management decisions affecting destination planning, marketing, natural preservation, and resident as well as visitor experiences. Visualization and analysis of demand markets are significantly enhanced by the capabilities of Geographic Information System (GIS) technology and help to support management objectives. The study [7] implements traditional desktop GIS as well as a free, web-delivered decision-support tool for tourism planning and marketing to assess $\sim 7.5$ million overnight accommodation reservations made for federal recreational facilities between 1999 and 2007. Visitor origin frequency and median travel distance for overnight accommodations are summarized by visitor zip code and by facility. National results indicate: facilities in the west, the Great Lakes and the southern Appalachians regions draw overnight visitors from the greatest median distances; residents in the Northeast have the lowest per-capita utilization; residents within the south-central Midwest and central-west Southern States have the highest per capita utilization and tend strongly toward local overnight reservations. Three selected national park regions are used to illustrate destinations characterized by highly localized utilization (Hot Springs National Park, AR), both local and regional utilization (Yosemite National Park, CA) and regionally to nationally dispersed utilization with few local residents reserving overnight accommodations (Canyonlands National Park, UT). Market profiling derived from local, regional and national customer origin markets can help any tourism destination, including national parks and their gateway communities, make smarter management and marketing decisions.

Evaluation of the tourism market in Georgia is given in the works [8-12]. The article [8] analyses prospects for the development of small tourism business in Georgia, in particular in rural settlements - so-called "rural tourism" (agritourism, farming tourism) which is a fast emerging sector of small entrepreneurship. Capabilities and conditions for the development of rural tourism are examined for different regions of Georgia. As it is noted, there are distinguishing characteristics in each region (natural environment, economic level, traditions of economic management, rules for family farm arrangement, rituals and customs, etc.) which differ regions from each other. Careful 
consideration is given to the objects which are of interest for agritourists in rural settlements in Georgian regions: Kakheti, mountainous area of Georgia (Svaneti, Racha-Lechkhumi, MtskhetaMtianeti), Achara, Guria, Samegrelo, Imereti, Shida and Kvemo Kartli, as well as to the issues of readiness for their acceptance. It is emphasized in the article [8] that the development of rural tourism in the country will promote economic growth in the regions, ensure employment of local people, improve their well-being, and, what is most crucially for mountainous regions, solve pressing demographic problem (depopulation of villages, ageing of population, young people's migration to urban areas, etc.). The main purpose of the article [9] is to analyse the peculiarities of tourism development and linkages between tourism sector and other branches of economy, especially agriculture, in the selected areas of Kazbegi Municipality - the town of Stepantsminda and villages of Sno and Juta. The research is focused on the socioeconomic aspects of tourism development, in particular, tourism services provided by local communities with emphasis on the influence of the family farming to the visitors' outlook with reference to the local agricultural products. It is notable that participant observation of stakeholders and in-depth interviews with native and inbound tourists was used to study the current stage and potential of the host communities in terms of tourism development. Based on the research authors argue that the observed rapid growth of tourist sector in the areas under investigation triggers economic growth, however the development is still fragmented and incomplete, as other branches of economy like agriculture, trade, etc., that should be connected to tourism activities, do not enjoy the expected growth. The paper [10] reviews the opportunities of ecotourism development in South Georgia, in particular, in the Gujareti valley located in Samtskhe-Javakheti region which has a rich tourism and recreation potential. Recreation areas with unused potential are strengthening the tourism and recreation cluster of Samtskhe-Javakheti with new capabilities. For this purpose the example and experience of Borjomi-Kharagauli National Park, natural conditions, balneology resources and medieval cultural heritage of the Gujareti valley have been studied. In the SWOT-table the supporting and obstructing factors of the development were analyzed. The general concept for landscape planning of spatial zoning were worked out, which envisages the protection of natural diversity, prospects of cultural, educational, healthcare tourism and supports interests of local communities, in terms of ecotourism promotion and creates a positive environment for organic agriculture. The Caucasus has its dignified place among 34 "Hot spots" of biological diversity identified on earth. Georgia is considered among 200 global eco-regions identified by the World Wildlife Fund (WWF). A number of animal and plant species spread in Georgia is included in the Red List of Georgia and Red List of the International Union for Conservation of Nature (IUCN). Consequently, the importance of ecotourism in Georgia is always a topical issue setting important tasks to ecotourism management [11].

Considered peripheral in economic terms the structurally fragile Armenia and Georgia with obvious limitations are open to international business. The article [12] constructs a compact analytical synthesis of the duo's potential across macroeconomic, industrial, external exposure risk, institutional, and the Diaspora (dispersion) effects within the five forces model of the social and economic transformation. Post-Great Recession dynamic analysis, sketching sectoral and business trends, tackles issues of market entry and foreign investor strategy. Armenia's impressive pre-crisis pattern has yet to be recovered, while Georgia's post-crisis record has been more consistent with earlier years. Armenia's entrepreneurial and innovative capacity, vital to new business accommodation, ranks above Georgia's, where traditional sectors are dominant. All in all there is a need for an individual, not "bulk", analysis of the post-socialist periphery. Foreign firms' managers are suited to gain if acquire local context and local (or Diaspora-) based partner (public or private) prior to regional or standalone entry. Despite multiple headwinds, both economies retain strong international business potential and hope for an economic and social resurrection.

Often, the issues of further development of international tourism in Georgia were solved by administrative methods, without sufficient analysis of the possibilities of this sector of the tourism industry. It should be noted that the issues of further development of international tourism and 
methodological tools and recommendations are not sufficiently developed and require further development.

Task statement. The aim of the work is to analyze the current state of international tourism in Georgia. On this basis, a set of activities and practical recommendations to improve the competitiveness of the tourism market of Georgia in the world market of international tourism services has been developed. Also, promoting the growth of the number of international tourists directly affects the development of the country's economy.

The need to achieve the goal of the study required the following tasks:

- study of the current state of the tourism market and service sector in Georgia, as the largest tourist region of Transcaucasia;

- analysis to identify "bottlenecks" in meeting the needs of international tourists and in the organization of international tourism;

- development of practical recommendations for improving the competitiveness of the international tourism market and improving the organization of international tourism.

The object of research is the existing tourist infrastructure of Georgia.

The subject of the study is a set of activities aimed at improving the competitiveness of the tourism market of international tourism in Georgia.

In the process of work General scientific methods were used: methods of induction and deduction, statistical methods, dialectical approach, the principle of logical and systematic analysis and synthesis, methods of comparative analysis, analytical and statistical international collections and publications of the world tourism organization.

Basic material and results. Recently, there has been a boom in international tourism in Georgia. In modern conditions the number of foreign tourists and income from international tourism has increased dramatically. For the year 2018, the number of international tourists amounted to 8 679544 (2017 7509902 people; growth of 9.8\%). Revenues from international tourism in 2018 (forecast data) amounted to 3171425 thousand dollars USA (against 2704340 thousand dollars USA in 2017; the growth amounted to $17.3 \%$ ) (Table 1).

Table 1

Dynamics of the number of international tourists and income for 2013-2018 [13]

\begin{tabular}{|c|l|r|r|r|r|r|r|}
\hline \multirow{2}{*}{ Indicator } & \multicolumn{2}{|c|}{ Unit } & \multicolumn{7}{c|}{ Years } \\
\cline { 3 - 8 } & \multicolumn{1}{|c|}{2013} & 2014 & 2015 & 2016 & 2017 & 2018 \\
\hline 1 & \multicolumn{1}{|c|}{2} & 3 & 4 & 5 & 6 & 7 & 8 \\
\hline International entry & $\begin{array}{l}\text { Thousand } \\
\text { people }\end{array}$ & 5392,3 & 5515,6 & 5901,1 & 6350,8 & 7902,5 & 8679,5 \\
\hline Revenue & $\begin{array}{l}\text { Million dollars } \\
\text { USA }\end{array}$ & 1719,7 & 1787,1 & 1935,9 & 2097,4 & 2751,4 & 3171,4 \\
\hline
\end{tabular}

It should also be noted that according to preliminary data, the share of income from international tourism amounted to $7.9 \%$ of Georgia's GDP in 2018, and its share in the volume of service exports amounted to $68.3 \%$ [13].

We will provide information on accommodation facilities that operate on the territory of Georgia. It should be noted that the national tourism administration registered 2039 accommodation facilities, with 85707 beds. The number of beds is leading Adjara AR c 25899 (30.2\%) beds, the second place is occupied by Tbilisi with 20118 (23.5\%) beds, and the third place is SamtskheJavakhetskii region with 10250 (12.0\%) beds.

In 2018-2020, the construction of branded hotels continues in Georgia. These hotels include Intercontinental, Rooms Hotel, Hilton Garden Inn, Radisson Park Inn, Rixos Tbilisi, Hyatt Regence, Moxy Marriott, Pullman hotels \& Resort, Radisson BLU Telegraph, Ramada Encore, Golden Tulip and Marriott Autograph. It is planned the construction of 32 branded hotels with 7 926 beds, including in Tbilisi 14 hotels ((53,0\%) with 4200 beds), in Adjara 12 hotels ((29,5\%) 
with 2396 beds, in Telavi 2 hotels ((4,5\%) with 360 beds), in Bakuriani 2 ((4,5\%) with 360 beds), in Kutaisi 1 hotel ((1,5\%) with 120 beds) and in Gudauri 1 hotel ((1,5\%) with 120 beds).

Below are the TOP countries in the world, which are characterized by a larger number of foreign tourists in Georgia (Table 2) [13].

Table 2

Top countries for international arrivals

\begin{tabular}{|c|c|c|c|c|}
\hline \multirow{2}{*}{ Country } & \multicolumn{2}{|l|}{$\begin{array}{l}\text { Number of international entries into } \\
\text { Georgia, thousand people }\end{array}$} & \multirow{2}{*}{$\begin{array}{l}\text { Growth, } \\
\text { thousand people }\end{array}$} & Growth, \% \\
\cline { 2 - 3 } & 2017 & 2018 & +123054 & $+10,8 \%$ \\
\hline Azerbaijan & 1301556 & 1424610 & -18282 & $-1.4 \%$ \\
\hline Armenia & 1287168 & 1268886 & +91279 & $+9.1 \%$ \\
\hline Turkey & 1007276 & 1098555 & +30897 & $+21,8 \%$ \\
\hline Ukraine & 141,734 & 172631 & +122642 & $+485,3 \%$ \\
\hline Iran & 25273 & 147915 & +32726 & $+55,0 \%$ \\
\hline Israel & 59487 & 92213 & +12032 & $+32,7 \%$ \\
\hline Kazakhstan & 36777 & 48809 & +2963 & $+7,2 \%$ \\
\hline Poland & 41425 & 44388 & +4063 & $+11,0 \%$ \\
\hline Germany & 36826 & 40889 & &
\end{tabular}

The positive trend continues on the part of the EU countries. In 2018, an increase in the number of foreign tourists distinguished United Kingdom - an increase of 39.9\%; Netherlands (31.1\%); Spain (28.9\%); Lithuania (31.7\%); France (29.6\%); Germany (25.7\%), etc [13] .

In the tourist product, the hub (central) place is occupied by transport. In the study of the development of tourism, it is extremely important to determine its interdependence with the transport industry. Success in the generated tourist markets and adequate transport infrastructure is an essential condition for the development of any tourist center. In turn, the need for tourism is a powerful incentive for the rapid development of the transport industry. Tourism is completely dependent on transport, its safety, speed and comfort of tourists.

The transformation of tourism into a mass phenomenon generates a number of problems. These problems are related to transport services. This applies to public transport, specialized transport within the tourism organization.

The development of tourism and transport is an interrelated and interdependent process. But, in the scientific literature in the study of the relationship in the system of "tourism - transport", preference is given to transport. Its role and importance is recognized as an important factor in the development of tourism. This is natural and logical, since tourism is a relatively new socio economic phenomenon and is largely the result of the development of transport [14].

In 2018, international tourists crossed the State border of the country by various means of transport (Fig. 1) [15].

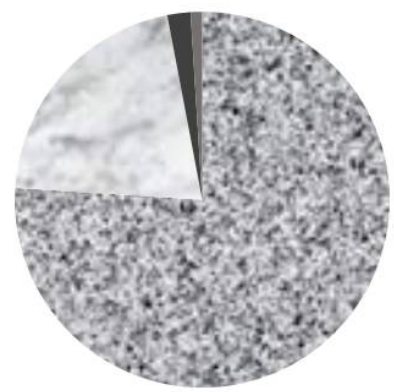

a Automotive $76 \%$

Aviation $21 \%$

Railway $2 \%$

Sea $1 \%$

Fig. 1. Crossing the border of Georgia by various means of transport, \%

The vast majority of international tourists entering by road is mainly due to the fact that among them are dominated by tourists from nearby countries (Armenia, Azerbaijan, Turkey, Iran, etc). In these countries due to the territorial proximity to Georgia and ease of movement tourists prefer road transport. At present, Georgia has railway communication only with Armenia and 
Azerbaijan. Sea passenger transportation is carried out from the seaport of Batumi in the direction of Odessa (Ukraine) and then in extremely small quantities.

Below is the dynamics of growth of international air flights and transported international air passengers for 2012-2017 from the airports of Georgia (Table 3) [13].

According to the statistics carried out by the national tourism administration [13], it was found that $52.3 \%$ of the total number of international visits to Georgia was carried out in Tbilisi and $29 \%$ in Batumi. In other cities and localities, fewer visits were recorded, including Marneuli (11.7\%), Mtskheta (9.9\%), Kazbegi (8.9\%), Gudauri (4.9\%), Sighnaghi (4.8\%), Kutaisi (4.6\%), Telavi (3.7\%) and Borjomi (3.4\%). When planning their trip, potential international tourists use a variety of information sources. In detail, $54.1 \%$ of tourists got information from friends or acquaintances, $15.7 \%$ of tourists got information from the Internet, and $14.6 \%$ of tourists got information from television/radio.

Table 3

Number of departures and passengers transported in 2012-2017

\begin{tabular}{|l|l|l|l|l|l|l|l|}
\hline \multicolumn{1}{|r|}{ Years } & 2012 & 2013 & 2014 & 2015 & 2016 & 2017 & 2018 \\
\hline $\begin{array}{l}\text { Number of flights } \\
\text { units }\end{array}$ & 11856 & 12653 & 13076 & 13667 & 15318 & 17159 & 19221 \\
\hline $\begin{array}{l}\text { Number of passengers, } \\
\text { thousand people }\end{array}$ & 1400,7 & 1833,1 & 2008,5 & 2261,1 & 2545,9 & 2864,7 & 3223,4 \\
\hline
\end{tabular}

The total expenditure of international visitors in 2018 amounted to 7.9 billion lari, the average expenditure per visit was 1099.1 lari. The largest share of expenditure was recorded for food and drink $(28.6 \%$ of total expenditure) and accommodation (23.4\%). Spending on recreational and cultural activities $(18.1 \%)$ was also represented by a significant share, while visitors spent only $13.6 \%$ of total spending on shopping (Table 4 ) [13].

Table 4

The structure of the international visitors expenses in 2018

\begin{tabular}{|c|c|c|}
\hline Cost components & Total expenses (thousand lari) & Weight, \% \\
\hline Food and drink & 2266881,1 & 28,6 \\
\hline Accommodation facilities & 1854514,2 & 23,4 \\
\hline $\begin{array}{c}\text { Recreation, cultural and } \\
\text { sports activities }\end{array}$ & 1434705,2 & 18,1 \\
\hline Shopping & 1074094,3 & 13,6 \\
\hline Local Transportation & 560769,3 & 7,1 \\
\hline Remaining expenses & 726539,9 & 9,2 \\
\hline Total & 7917503,9 & 100 \\
\hline
\end{tabular}

When making international visits, $95 \%$ of visitors did not use tourist packages. During international visits, $4.5 \%$ and $0.5 \%$ of visitors used tourist packages of foreign and domestic tour operators, respectfully. International visitors in 2018 span gel 804.9 million lari on the purchase of tourist packages (Fig. 2) [13].

In 2018, a significant number of events were held, which were aimed at attracting tourists. Georgia took part in 23 international exhibitions. Georgia also conducted active marketing campaigns, presentations and other events in various countries in the target markets. In 2018 alone, the national tourism administration organized the arrival of 750 journalists and 400 tour operators from different parts of the world to Georgia. As a result, they have prepared and published in their countries about 850 articles, dozens of television stories and documentaries about Georgia. 


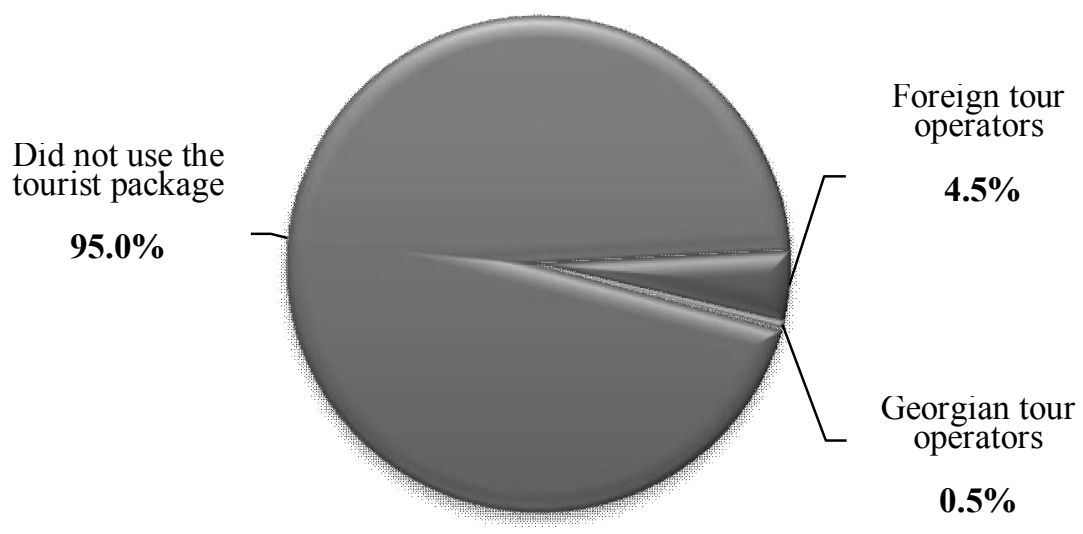

Fig. 2. Structure of tourist packages use by international visitors

In 2018, measures were taken to improve the competitiveness of international tourism and to occupy an appropriate place in the world tourism market. These procedures require competent personnel in this area, which is lacking. In order to improve the quality of service to tourists, various training courses are constantly functioning. In 2018, 1770 people were retrained in the tourism sector.

At the same time, the main reason for the insufficient use of the country's tourism potential is the poorly developed tourism infrastructure.

Among the priority problems that significantly reduce the competitiveness of the national tourism product are the following:

- permanent increase in the cost of inbound and domestic tourism product. This growth is caused by the increasing seasonality, the narrowness of the tourist offer, the concentration of internal and incoming tourist flows in certain tourist centers and resorts;

- uncompetitive quality of services offered to tourists, especially hotel and transport;

- insufficiently effective measures to promote the national tourism product in foreign and domestic markets;

- lack of common standards and indicators of statistical accounting in the field of tourism in the country;

- an acute shortage of qualified workers in the sphere of tourist services; - insufficiently effective instruments of state regulation of the tourism market.

It should be noted that in recent years (2008-2018) in the field of foreign tourism prices have increased by about $7.5 \%$. And at the same time, the cost of the internal conditional tour package by 2018 increased by almost a third. The outstripping growth in the cost of domestic tourism products is primarily due to the increase in prices for travel within the country, services, accommodation, catering and cultural institutions. The presence of unsatisfied demand for hotel services in the peak season itself leads to an increase in prices for them, a decrease in the quality of service. And as a result, it all leads to anti-advertising of the domestic hospitality industry. In raising prices, the lion's share belongs to aviation and railway companies, branded means of tourist accommodation.

With such price dynamics, the demand for trips to Georgia is preserved due to the truly unique natural and cultural heritage.

In important problem is the lack of accommodation facilities that meet modern standards of hotel service. Increasing the load of existing hotels requires new marketing approaches to the formation of tourism products, taking into account seasonal fluctuations in demand for services of various types of accommodation, in particular, tourist hotels and business class hotels. We are talking about the development of incentive tourism, Congress tourism and offer attractive offseason tourism products (winter, vacation, event). The creation of such a product is the business of market participants and regional governments themselves. But without government support, it will be difficult to promote new products to the market. This is possible only if the development and 
implementation of a more effective system of advertising and information support for the development of domestic and inbound tourism.

An urgent problem of the development of international tourism in Georgia is the improvement of transport services. On the basis of a survey of foreign tourists at the Tbilisi airport, most of the claims in terms of the organization of travel in Georgia is expressed in relation to transport services. The latter is largely due to the high physical and moral deterioration of fixed assets of passenger transport and transport infrastructure.

Given the resource constraints in the near future, the focus should be not so much on largescale (expensive advertising campaigns abroad) as on providing foreign citizens with the fullest possible information about travel opportunities in Georgia.

Given the resource constraints in the near future, the focus should be not so much on largescale (expensive advertising campaigns abroad) as on providing foreign citizens with the fullest possible information about travel opportunities in Georgia.

The solution to the problem of increasing the competitiveness of the Georgian tourism market also lies in the creation of basic internal conditions. The primary among them is the dynamic development of the tourism industry and the expansion of its position in the national economy. Of fundamental importance is the improvement of the structure of the tourism industry: the predominant development of less well-known tourist destinations, increasing the share of tours with the maximum multiplier effect; promotion of tourism relationships with partner countries of Georgia and border States.

Participation of Georgia in the global tourism policy, expansion of its international cooperation in the tourism sector is an important trend. In the context of the General national policy, the local specifics of tourism supply and demand, the current and planned level of tourism development in the regions and individual centers are taken into account to the maximum extent. It is important to improve international tourism through the preservation and use of elements of local natural, historical and cultural heritage, as well as to increase the socio-economic effect of the development of international tourism activities (growth of income, production, employment). This is one of the most important modern trends in the development of the world tourism market.

To create a world-class tourism product and stimulate both international and domestic needs, the country must solve the following problems:

- deepening cooperation between the public and private sectors in different areas;

- provision of convenient and affordable air services from major tourist markets;

- improvement of access roads to the most important tourist destinations and improvement of the relevant infrastructure;

- preservation of cultural heritage and other cultural assets; improvement of their accessibility, existing services and interpretation infrastructure;

- raising awareness of the country's tourism potential in both international and domestic markets;

- improvement of the system of education in the field of tourism and ensuring the availability of educational programs throughout the country;

- offering a new tourism product and diversifying the existing one.

In order to further improve the tourism industry of Georgia in the world market, the Ministry of economy and sustainable development of Georgia and the national Department of tourism of Georgia developed the "tourism strategy of Georgia 2025". This strategy presents a 10-year strategic plan to ensure the sustainable growth of the tourism industry in Georgia and to ensure the growth of job creation opportunities.

According to the strategy, the following objectives were defined:

- improvement of the internal transport network in order to ensure the consolidated movement of visitor flows across the country;

- creating opportunities for visitors to get a unique and sublime experience using the cultural and natural resources of the country; 
- improvement of visitor services (in terms of transportation, accommodation and language skills);

- improvement of possibilities of data collection and market research for a more qualified assessment of the needs of tourism markets with high payment ability;

- use of the mentioned research and additional marketing resources in order to more effectively develop tourism markets with high payment capacity, establish strong ties with them and increase recognition of Georgia as a world-class tourist destination.

In order to achieve the goals set by the strategic tourism program of Georgia and achieve the world level of competitiveness of the country tourism market, it is necessary to solve the following priorities:

- growth of public and private investment in tourism;

- improving the business environment to increase foreign and local investment;

- with the help of effective marketing and information company to attract visitors from tourist markets with high payment capacity;

- increasing competitiveness through the provision of tourism services at the global level;

- respect, protection and promotion of natural and cultural heritage of Georgia in the world tourism markets.

Conclusions. In order to further develop the international tourism market of Georgia and solve the above-mentioned problems, it is necessary to establish partnership relations between the state, representatives of the tourism industry, non-governmental organizations and the local population. All this will contribute to a sharp increase in recognition of Georgia in the world tourism market and raise international tourism to a qualitatively new level.

\section{REFERENCES:}

1. Crainer, S. Ultimate Book of Business Brands: Insights from the World's 50 Greatest Brands. Textbook / S. Crainer, D. Dearlove. - Capstone, 2002. - 246 p.

2. Crainer, S. The Ultimate Business Library: The Greatest Books That Made Management / S. Crainer. -San Val, 2002. - 346 p.

3. Cockerell, L. The Customer Rules : The 39 Essential Rules for Delivering Sensational Service. Textbook / L. Cockerell. - The Crown Publishing Group, 2013. - 208 p.

4. Lin, Z. Segmenting global tourism markets: A panel club convergence approach / Z. Lin, You K, C. K. Lau, E. Demir // Annals of Tourism Research. - Elsevier, 2019. - Volume 75.- P. 165 - 185. https://doi.org/10.1016/j.annals.2019.01.007

5. Pulido-Fernández, J. I. Does environmental sustainability contribute to tourism growth? An analysis at the country level / J. I. Pulido-Fernández, P. J. Cárdenas-García, J. A. EspinosaPulido // Journal of Cleaner Production . - Elsevier, 2019. - Volume 213.- P. 309 - 319. https://doi.org/10.1016/j.jclepro.2018.12.151

6. Assaf, A. G. The estimation and decomposition of tourism productivity / A. G. Assaf, M. Tsionas // Tourism Management. - Elsevier, 2018. - Volume 65.- P. 131 - 142. https://doi.org/10.1016/j.tourman.2017.09.004

7. Brothers, G. Geospatial analytics for federally managed tourism destinations and their demand markets / G. Brothers, D. W. Bohnenstiehl, H. Devine // Journal of Destination Marketing \& Management. - Elsevier, 2015. - Volume 4.- $\quad$ P. 173 - 186. https://doi.org/10.1016/j.jdmm.2015.05.002

8. Paresishvili, O. Rural tourism as a promising trend of small business in Georgia: Topicality, capabilities, peculiarities / O. Paresishvili, L. Kvaratskhelia,V. Mirzaeva // Annals of Agrarian Science. - Elsevier, 2017. - Volume 15.- P. 344 - 348. https://doi.org/10.1016/j.aasci.2017.07.008

9. Gugushvili, T. Fragmented development: Tourism-driven economic changes in Kazbegi, Georgia / T. Gugushvili, G. Salukvadze, J. Salukvadze // Annals of Agrarian Science. - Elsevier, 2017. - Volume 15.- P. 49 - 54. https://doi.org/10.1016/j.aasci.2017.02.005 
10. Khoshtaria, T.K. Prospects of ecotourism development in recreation areas of South Georgia / T.K. Khoshtaria, N.T. Chachava // Annals of Agrarian Science. - Elsevier, 2017. Volume 15.- P. 312 - 317. https://doi.org/10.1016/j.aasci.2017.07.004

11. Paresashvili, N. Major Tasks of Ecotourism Management in Georgia / N. Paresashvili // Procedia - Social and Behavioral Sciences. - Elsevier, 2014. - Volume 156.- P. 170 - 173. https://doi.org/10.1016/j.sbspro.2014.11.164

12. Gevorkyan, A.V. The legends of the Caucasus: Economic transformation of Armenia and Georgia / A.V. Gevorkyan // International Business Review. - Elsevier, 2015. - Volume 24.- P. 1009 - 1024. https://doi.org/10.1016/j.ibusrev.2014.12.002

13. Statistical review of tourism in Georgia (in Georgian). - Tbilisi, 2019. usfs

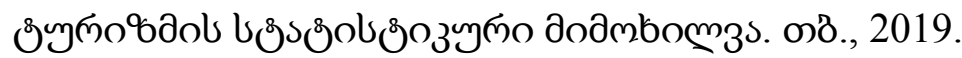

14. Meladze M. Features of tourist product formation in Georgia (in Georgian) // M.

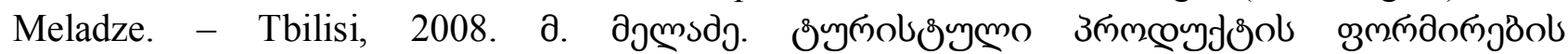

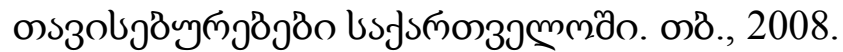

15. Operational data of the Ministry of internal Affairs of Georgia for 2018 (in Georgian). -

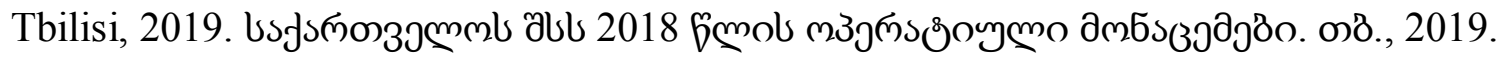

\section{УДК 338.48}

JEL classification: D 47

Девадзе Анзор Хемидович, кандидат економічних наук, професор факультету туризму, керівник департаменту туризму. Батумський державний університет імені Шота Руставелі. Кордзаія Іраклій Ахмедович, доктор адміністрування бізнесу, асистент професор факультету туризму. Батумський державний університет імені Шота Руставелі. Чичуліна Ксенія Вікторівна, кандидат технічних наук, доцент. Полтавський національний технічний університет імені Юрія Кондратюка. Проблеми вдосконалення міжнародного туристичного ринку Грузії. Виконано аналіз сучасного стану міжнародного туризму Грузії. На цій основі розроблено комплекс заходів і практичних рекомендацій для підвищення конкурентоспроможності туристичного ринку Грузії на світовому ринку міжнародних туристичних послуг, що безпосередньо впливає на розвиток економіки країни. Також стверджується, що сприяння зростанню кількості міжнародних туристів безпосередньо впливає на розвиток економіки країни. Грузія завдяки геополітичному розташуванню й існуючим природним, історичним та культурним ресурсам має практично необмежені ресурси розвитку міжнародного туризму. Разом 3 тим туристичний потенціал країни використовується недостатньо ефективно, i головна причина цього полягає в слабо розвинутій інфраструктурі туризму. Здійснено аналіз існуючого стану розвитку ринку міжнародного туризму й розкрито актуальні проблеми, що стримують його розвиток у Грузії. Для досягнення цілей, намічених стратегічною програмою туризму Грузії, $\mathrm{i}$ досягнення світового рівня конкурентоспроможності туристичного ринку країни необхідне розв'язання таких першочергових завдань: зростання державних та приватних інвестицій у сфері туризму; удосконалення бізнес-середовища з метою збільшення іноземних і місцевих інвестицій; за допомогою ефективного маркетингу та інформаційної кампанії залучення візитерів 3 туристичних ринків 3 високою платіжною здатністю; зростання конкурентоспроможності за допомогою пропозиції туристичного обслуговування на світовому рівні; повага, охорона і просування на світових туристичних ринках природної та культурної спадщини Грузії. Для подальшого розвитку міжнародного туристичного ринку країни і розв'язання вищеперелічених завдань необхідним є встановлення партнерських взаємовідносин між державою, представниками туристичної індустрії, неурядовими організаціями та місцевим населенням. Це сприятиме підвищенню пізнаваності Грузії на світовому туристичному ринку і піднесенню міжнародного туризму на якісно новий рівень.

Ключові слова: міжнародний туризм, туристичний ринок, туристичний потенціал, туристичний продукт, туристична індустрія, політика туризму. 


\section{UDC 338.48}

JEL classification: D 47

Devadze Anzor, Ph.D, Professor of Tourism Faculty, Head of Tourism Department. Batumi Shota Rustaveli State University. Kordzaia Irakli, D.Sc., Assoc. Professor of Tourism Faculty, Batumi Shota Rustaveli State University. Chichulina Kseniia, Ph.D., Assoc. Professor of Management and Logistic Department. Poltava National Technical Yuri Kondratyuk University. Problems of the international tourism market improvement in Georgia. The paper analyzes the current state of the international tourism market development and presents current problems hampering its development in Georgia. Based on this analysis, the authors offer practical recommendations to improve the competitiveness of the tourism Georgia market in the world market of international tourism services. This has a direct impact on the economic development of the country.

Keywords: business processes, business model, enterprise, reengineering, logistic concept, classification criteria.

\section{УДК 338.48}

JEL classification: D 47

Девадзе Анзор Хемидович, кандидат экономических наук, профессор факультета туризма, руководитель департамента туризма. Батумский государственный университет имени Шота Руставели. Действительный член Академии наук бизнеса Грузии. Кордзаия Ираклий Ахмедович, доктор администрирования бизнеса, ассистент профессор факультета туризма. Батумский государственный университет имени Шота Руставели. Чичулина Ксения Викторовна, кандидат технических наук, доцент. Полтавский национальный технический университет имени Юрия Кондратюка. Проблемы совершенствования международного туристического рынка Грузии. Проведен анализ существующего состояния рынка международного туризма, представлены актуальные проблемы, сдерживающие его развитие в Грузии. На основе этого анализа авторами статьи предложены практические рекомендации для повышения конкурентоспособности туристического рынка Грузии на мировом рынке международных туристических услуг, что непосредственно влияет на развитие экономики страны.

Ключевые слова: международный туризм, туристический рынок, туристический потенциал, туристический продукт, туристическая индустрия, политика туризма. 